\title{
Influence of Nanosilica on Workability and Compressive Strength of Wood Ash Cement Concrete
}

\author{
${ }^{1 *}$ Raheem, A. A.; ${ }^{2}$ Lateef, A.; ${ }^{1}$ Akinola, P.O.; ${ }^{1}$ Adeniyi, A. A. and ${ }^{1}$ Yusuf, S. O. \\ ${ }^{1}$ Department of Civil Engineering, LAUTECH, PMB 4000, Ogbomoso, Nigeria. \\ ${ }^{2}$ Department of Pure and Applied Biology, LAUTECH, PMB4000, Ogbomoso, Nigeria. \\ *Corresponding author: aaraheem@lautech.edu.ng
}

\begin{abstract}
Studies have revealed that wood ash cement concrete just like other pozzolanic cement concrete has lower early strength compared to plain cement concrete. Nanoparticles have been found to improve the early strength of concrete due to its small size and large surface area. This paper reports the influence of nanosilica on the workability and compressive strength of wood ash cement concrete. Wood ash was obtained as a waste product from Ladoke Akintola University of Technology (LAUTECH) bread bakery, Ogbomoso. Biological synthesis of nanosilica using kola Pod extract and silica precursor (1:5) was conducted at Nanotechnology research group laboratory at LAUTECH. The chemical composition, specific gravity and particle size distribution of wood ash, fine and coarse aggregate used were determined. Concrete with 10\% wood ash replacement for cement was produced using 1:2:4mix proportion and water to binder ratio of 0.5.Nanosilica was added at 0.5, 1.0, 1.5 and 2.0\% levels. Concrete with no wood ash and nanosilica served as the control. Workability and compressive strength of the plain and composite concrete were determined. The results showed that concrete workability was enhanced with introduction of nanosilica. The compressive strength also increased with addition of nanosilica. Maximum compressive strength of 27.53MP was achieved at 90 days with 1.5\% nanosilica addition. It was concluded that nanosilica enhanced workability and improved both early and later strength development in wood ash concrete with $1.5 \%$ as the optimum addition.
\end{abstract}

Keywords: Woodash, cement, concrete, Nanosilica, Workability and Compressive strength.

\section{Introduction}

Concrete is a versatile and relatively economical construction material with unlimited application in buildings and other civil engineering structures. It is a composite mixture of cement, fine aggregate (sand), coarse aggregate (gravel or crushed stone) and sometimes chemical admixtures or mineral additives. Pozzolans can be used as supplementary cementitious materials (SCM) or as mineral additives in Concrete.

Several researchers have investigated the use of pozzolan such as coal fly ash, rice husk ash, corn cob ash, sawdust ash, wood ash, etc. to partially replace energy intensive cement (with non-environmental friendly by-product) in the production of concrete (Antiohos, 2005; Raheem and Kareem, 2017; Adesanya and Raheem, 2009; 2010; Raheem et al., 2012; Raheem and Adenuga, 2013). In finely divided form and in the presence of water, these SCM react with calcium hydroxide a by-product of cement hydration to form calcium-silicate-hydrate and other cementitious hydrate compounds. Studies have shown that concrete containing pozzolan have lower early age strength as compared to plain cement concrete but shows greater improvement than plain cement concrete at later ages (Adesanya and Raheem, 2009; Raheem et al., 2012; Chowdhury et al., 2015).

Wood ash is a product of wood combustion that possesses pozzolanic property. Several researchers had worked on partial replacement of cement in concrete with wood ash (Abdullahi, 2006; Udoeyo, 2006; Siddique, 2012; Raheem and Adenuga, 2013; Chowdhury et al., 2015). All the studies showed that the inclusion of wood ash as partial replacement for cement has adverse effect on some properties of concrete. A study by Abdullahi (2006) showed that the compressive strength of plain cement concrete $(23.96 \mathrm{MPa})$ was greater than that of wood ash concrete $(14.13 \mathrm{MPa})$ at age 28 days. However, at 60 -day 
curing age, the compressive strength of wood ash concrete increased by $32 \%$ compared to $0.79 \%$ increase in plain cement concrete. Also, according to Chowdhury et al. (2015), splitting tensile strength of wood ash concrete decreased with increase in percentage of wood ash. In the same vein, Udoeyo et al. (2006) asserted that concrete specimens absorbed more water as the wood ash content increased. These negative effects of partial replacement of cement with wood ash need to be tackled so as to maintain the integrity of the concrete. This led us to the incorporation of nanoparticles in pozzolan concrete.

Nanoparticles are highly reactive materials which have been used to improve the structural efficiency, durability and strength of concrete. The addition of nanoparticles accelerates chemical reaction during initial hydration thereby strengthening cement composites. The addition of $\mathrm{TiO}_{2}, \mathrm{Al}_{2} \mathrm{O}_{3}, \mathrm{SiO}_{2}$ and $\mathrm{Fe}_{2} \mathrm{O}_{3}$ nano particles have been shown to improve concrete properties by creating a more compact microstructure which not only decrease permeability, but also enhance mechanical properties (Sikora et al. 2018; Mahender and Ashok, 2017; Bera et al., 2012; Nazari and Riahi, 2011a; 2011b; 2011c).According to Nazari and Riachi (2011c), addition of nano silica up to 4\% increased the early age compressive strength of concrete. The study showed that concrete incorporated with $4 \%$ of nano silica showed improvement of $49 \%, 101 \%$ and $74 \%$ relative to conventional concrete at 2-day, 7-day and 28day curing ages, respectively. Nazari and Riahi (2011a) reported that concrete specimens containing $\mathrm{Al}_{2} \mathrm{O}_{3}$ nanoparticles have significantly higher compressive strength when compared with conventional concrete at every age of curing. In this study, the influence of nanosilica on workability and compressive strength of wood ash cement concrete was investigated.

\section{Materials and Methods}

\section{Materials}

Ordinary Portland cement of grade 42.5 in accordance with (BS 12: 1996) was used. Natural river sand obtained locally was used as fine aggregates. Crushed granite stone from local quarries was used as coarse aggregate with maximum size of $19 \mathrm{~mm}$. Wood ash was obtained as a waste product from Ladoke Akintola University of Technology (LAUTECH) Ogbomoso, Nigeria, bread bakery. The wood ash was collected the bakery with the aid of hand scoop from the exhaust of the oven after the fuel has been completely burnt. Biological synthesis of nanosilica using cola pod extract and silica precursor (1:5) was conducted at nanotechnology research group laboratory at LAUTECH.

\section{Testing of Materials}

The collected wood ash was analyzed by (Raheem and Adenuga, 2013) at West Africa Portland Cement Company (WAPCO) Sagamu, Ogun state, Nigeria, to determine its chemical composition. The analysis of the ash was carried out using X-ray Fluorescence Analyser (Model QX 1279). The specific gravity of the ash was also determined.

Sieve analysis was performed to determine the particle size distribution of the wood ash, fine and coarse aggregates. The coefficient of uniformity $\left(\mathrm{C}_{\mathrm{u}}\right)$ and coefficient of curvature $\left(\mathrm{C}_{\mathrm{c}}\right)$ of the fine and coarse aggregates were obtained so as to classify them and assess their suitability.

\section{Specimen Preparation}

The concrete mix ratio used was 1:2:4 with water-cement ratio of 0.5. Six mix proportions were prepared. Sample A was normal concrete with no wood ash and nanosilica. Sample B was prepared by replacing $10 \%$ of cement with wood ash. Sample C, D, E and F had 0.5, 1, 1.5 and $2 \%$ of nansilica by weight of cement, respectively added to the concrete mix. Table 1 shows the mix proportion by weight of the materials in each sample. 
LAUTECH Journal of Civil and Environmental Studies

Volume 2, Issue 1; 2019

Table 1: Proportioning of Concrete

\begin{tabular}{ccccccc}
\hline Sample & $\begin{array}{c}\text { Percentage of } \\
\text { Nano silica } \\
(\%)\end{array}$ & $\begin{array}{c}\text { Cement } \\
(\mathrm{kg})\end{array}$ & $\begin{array}{c}\text { Wood ash } \\
(\mathrm{kg})\end{array}$ & $\begin{array}{c}\text { fine } \\
\text { aggregate } \\
(\mathrm{kg})\end{array}$ & $\begin{array}{c}\text { Coarse } \\
\text { aggregate } \\
(\mathrm{kg})\end{array}$ & $\begin{array}{c}\text { Nano } \\
\text { silica } \\
(\mathrm{kg})\end{array}$ \\
\hline $\mathrm{A}$ & 0.00 & 25.63 & 0.00 & 51.25 & 102.5 & 0.00 \\
$\mathrm{~B}$ & 0.00 & 23.07 & 2.56 & 51.25 & 102.5 & 0.00 \\
$\mathrm{C}$ & 0.50 & 23.07 & 2.56 & 51.25 & 102.5 & 0.13 \\
$\mathrm{D}$ & 1.00 & 23.07 & 2.56 & 51.25 & 102.5 & 0.26 \\
$\mathrm{E}$ & 1.50 & 23.07 & 2.56 & 51.25 & 102.5 & 0.39 \\
$\mathrm{~F}$ & 2.00 & 23.07 & 2.56 & 51.25 & 102.5 & 0.52 \\
\hline
\end{tabular}

Testing of specimens

Workability of each sample was assessed by conducting slump and compacting factor tests in accordance with (BS 1881: Part 102-83) and (BS 1881: Part 103-83), respectively. Compressive strength test was carried out on $150 \mathrm{~mm}$ cube concrete specimens. The specimens were cast in three layers, each layer was tampered uniformly across the cross-section of each layer with 25 strokes of the tamping rod. The top layer of each mould was leveled and smoothened and the outside surface cleaned. All specimens were demoulded after 24 hours and cured in water. The compressive strength was determined at curing ages 3 , 7, 28 and 56 days using compression machine with maximum capacity of $1500 \mathrm{kN}$ (Model 50- C34AC and Serial no 02094910). The compressive strength of each sample was the average of three specimens.

\section{Results and Discussion}

\section{Chemical Composition}

The elemental oxides present in the wood ash sample are shown in Table 2. The result indicated that the wood ash had combined percentages of $\mathrm{SiO}_{2}, \mathrm{Al}_{2} \mathrm{O}_{3}$ and $\mathrm{Fe}_{2} \mathrm{O}_{3}$ of $73 \%$. This result is similar to that of Chowdhury et al. (2015) with wood ash having combined silica, alumina and ferric oxide of $71.79 \%$. This indicates that the present wood ash is a good pozzolanic material in accordance with the requirements in ASTMC 618. As reported by Jerath and Hanson (2007), wood ash from bread bakery falls under the category of class $\mathrm{F}$ fly ash since the sum of $\left(\mathrm{SiO}_{2}+\mathrm{Al}_{2} \mathrm{O}_{3}+\mathrm{Fe}_{2} \mathrm{O}_{3}\right)$ is greater than $70 \%$.

Table 2: Chemical Composition of Wood Ash

\begin{tabular}{ccccc}
\hline Chemical Constituents & \multicolumn{4}{c}{ Percentage Composition (\%) } \\
& Sample 1 & Sample 2 & Sample 3 & Average \\
\hline $\mathrm{SiO}_{2}$ & 61.12 & 62.75 & 61.74 & 61.18 \\
$\mathrm{Al}_{2} \mathrm{O}_{3}$ & 7.05 & 7.95 & 7.57 & 7.52 \\
$\mathrm{Fe}_{2} \mathrm{O}_{3}$ & 3.22 & 2.91 & 3.44 & 3.19 \\
$\mathrm{CaO}$ & 10.56 & 12.94 & 11.88 & 11.77 \\
$\mathrm{MgO}$ & 2.34 & 2.00 & 3.11 & 2.48 \\
$\mathrm{SO}$ & 1.84 & 1.80 & 1.82 & 1.82 \\
$\mathrm{Na}_{3} \mathrm{O}$ & 1.15 & 1.00 & 1.11 & 1.09 \\
$\mathrm{~K}_{2} \mathrm{O}$ & 3.56 & 4.11 & 3.75 & 3.81 \\
$\mathrm{CaCO}_{3}$ & 6.12 & 6.22 & 6.31 & 6.22 \\
$\mathrm{LOI}$ & 2.95 & 3.20 & 2.99 & 3.05 \\
$\mathrm{LSF}$ & 1.2 & 1.37 & 1.27 & 1.28 \\
$\mathrm{SR}$ & 4.15 & 4.25 & 4.56 & 4.32 \\
$\mathrm{AR}$ & 7.48 & 7.56 & 7.62 & 7.55 \\
Total $\mathrm{SiO}_{2}+\mathrm{Al}_{2} \mathrm{O}_{3}+\mathrm{Fe}_{2} \mathrm{O}_{3}$ & 71.39 & 73.61 & 72.75 & 72.58 \\
\hline
\end{tabular}




\section{Specific Gravity}

Table 3 shows the results for the specific gravity of wood ash. The specific gravity of wood ash was found to be 2.28. This result is within the range of values obtained by (Udoeyo et al., 2006).

Table 3: Wood Ash Specific gravity

\begin{tabular}{ccccc}
\hline & Trial 1 & Trial 2 & Trial 3 & Average \\
\hline $\begin{array}{c}\text { Mass of density bottle } \\
(\mathrm{g})\end{array}$ & 25 & 25 & 25 & 25 \\
$\begin{array}{c}\text { Mass of density bottle + } \\
\text { wood ash (g) } \\
\begin{array}{c}\text { Mass of density bottle + } \\
\text { wood ash + water }(\mathrm{g})\end{array}\end{array}$ & 34 & 34 & 32 & 33.33 \\
$\begin{array}{c}\text { Mass of density bottle }+ \\
\quad \text { water (g) }\end{array}$ & 72 & 77 & 76 & 76.67 \\
Specific gravity & 2.25 & 72 & 72 & 72 \\
\hline
\end{tabular}

Sieve Analysis

The results of the sieve analysis for wood ash, fine and coarse aggregates is presented in figure 1 . The coefficient of uniformity $\left(\mathrm{C}_{\mathrm{u}}\right)$ and coefficient of curvature $\left(\mathrm{C}_{\mathrm{c}}\right)$ of the wood ash are 2.86 and 1.23 respectively, thus, the wood ash is classified as uniformly graded (Smith and Smith, 1998). Similarly, the $\mathrm{C}_{\mathrm{u}}$ and $\mathrm{C}_{\mathrm{c}}$ for fine aggregates and coarse aggregates are 4.11, 1.09 and 4.10, 1.01 respectively. The coefficient of uniformity gives an indication of the spread of particles sizes (Bowles, 1992). Since both values of the coefficient of uniformity fall between 1.0 and 5.0, it can be concluded that the fine and coarse aggregates are uniformly graded and are therefore suitable for making good concrete.

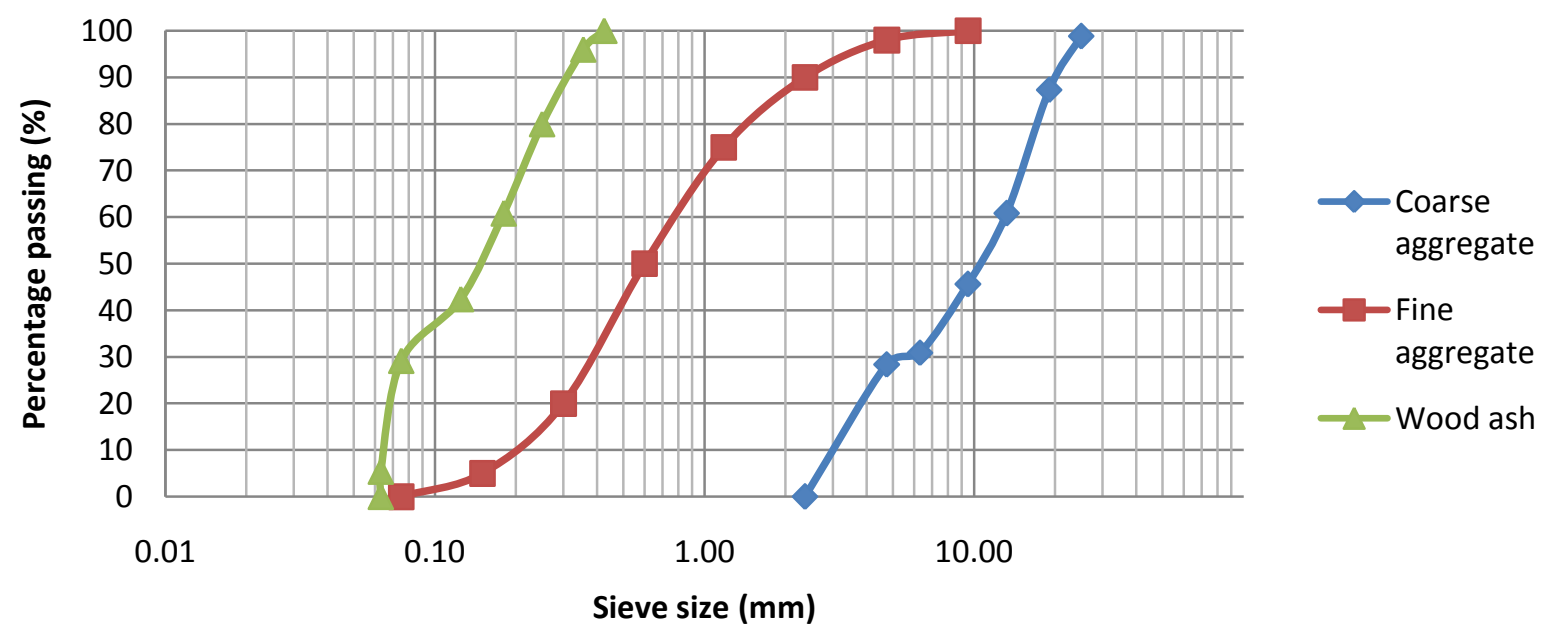

Figure 1: Particle Size distribution graph of Wood Ash, Fine Aggregate and Coarse Aggregate.

\section{Workability}

The results of the slump and compacting factor tests are presented in Table 4. It is evident from the results that wood ash concrete has lower workability than plain concrete at the same water-binder ratio. Plain cement concrete without wood ash and nanosilica (Sample A) had a slump of $65 \mathrm{~mm}$ and compacting 
factor of 0.94. Sample B with $10 \%$ Wood ash content and without nano silica had a slump value of $45 \mathrm{~mm}$ and compacting factor value of 0.91. This shows that sample A is more workable than sample B. This is in line with the findings of Udoeyo et al. (2006) and Abdullahi (2006) that wood ash cement concrete requires additional water relative to plain cement concrete to achieve a reasonable workability. However, addition of more water is detrimental to the strength property of concrete. This problem is solved with the incorporation of nanosilica into the wood ash concrete. With the addition of $0.5 \%$ nanosilica into the wood ash concrete (Sample C), the slump and compacting factors increased to 50mm and 0.94, respectively. The trend continued, with wood ash concrete containing $2.0 \%$ nanosilica having the highest slump and compacting factor of $70 \mathrm{~mm}$ and 0.97 , respectively. Thus, the workability of wood ash concrete increased with the introduction of nanosilica into the mix.

Table 4: Slump and Compacting Factor of Wood Ash Cement Concrete

\begin{tabular}{ccc}
\hline Sample & Slump $(\mathrm{mm})$ & Compacting factor \\
\hline A & 65 & 0.94 \\
B & 45 & 0.91 \\
C & 50 & 0.94 \\
D & 60 & 0.95 \\
E & 65 & 0.96 \\
F & 70 & 0.97 \\
\hline
\end{tabular}

\section{Compressive Strength}

The compressive strength of concrete samples is presented in Figure 2.It can be observed from the figure that the addition of nanosilica generally increased the compressive strength at both early and later curing ages.

At 3 days, sample $\mathrm{B}$ had the lowest compressive strength (10.74MPa) below plain cement concrete $(10.89 \mathrm{MPa})$. The compressive strength of wood ash concrete increased with increase in percentage of nanosilica up to $1.5 \%$ addition. Samples C, D and Ewith $0.5,1.0$ and $1.5 \%$ nanosilica addition had compressive strength of 10.96, 11.12 and $12.59 \mathrm{MPa}$, respectively. However, the strength dropped at $2 \%$ addition to $11.19 \mathrm{MPa}$. The increase in compressive strength is due to faster pozzolanic reactivity of nanoparticles, in the presence of $\mathrm{Ca}(\mathrm{OH})$, making the microstructure denser ( Ghafari et al. (2014). According to Lin et al. (2008), the incorporation of nanosilica can accelerate the hydration process of $\mathrm{C}_{3} \mathrm{~S}$ clinker phase due to the large and highly reactive surface of nanoparticles. The decrease in strength at $2 \%$ nanosilica addition could be attributed to improper dispersion of nanoparticles in the mixture. As reported by Ghafari et al. (2014), when nanoparticles are added in excess to the mixture, these are not uniformly dispersed in the cement paste and as a consequence, week areas appear in the concrete due to agglomeration.

Similar trends were observed at 7 and 28 days. The compressive strength of all the samples improved relative to the 3 -day strengths. At 7 days, sample B had the lowest compressive strength (11.41MPa) below that of sample A $(12.00 \mathrm{MPa})$. The compressive strength then increased with increase in percentage of nanosilica up to $1.5 \%$. Sample E had the highest compressive strength (17.33MPa). At 28 days, sample A still had higher compressive strength than sample B. Addition of nanosilica at $0.5 \%$ improved the compressive strength of concrete over both sample A and sample B concretes. At $1 \%$ addition, there was an insignificant $(0.22 \%)$ drop in strength. Addition of nanosilica at $1.5 \%$ gave the highest compressive strength value (21.63MPa) while $2.0 \%$ addition has a reduced compressive strength of $14.11 \mathrm{MPa}$.

There was an anomalous reduction in 56 days compressive strengths of samples A and B relative to their 28 days strengths. This deviation can be attributed to experimental random errors. However, similar trend was followed as in previous curing ages. The compressive strength increased with increase in percentage 
of nanosilica addition up to $1.5 \%$ before dropping at $2.0 \%$ addition. At 90 days, there was rapid increase in compressive strength of all wood ash cement concrete samples (B, C, D, E, F) over that of 56 days. The difference between the compressive strength of sample B (15.97 MPa) and sample A (16.56MPa) is lower compared to earlier curing ages. The gain in compressive strength is due to pozzolanic reaction of wood ash cement concrete at later ages. The compressive strength increased from $17.42 \mathrm{MPa}$ at $0.5 \%$ nanosilica addition to $21.25 \mathrm{MPa}$ at $1.0 \%$ and $27.53 \mathrm{MPa}$ at $1.5 \%$ before dropping to $22.61 \mathrm{MPa}$ at $2.0 \%$. Recent study by Saloma et al. (2015), stated that rapid development of compressive strength of concrete with nano silica is an indication that the nanosilica not only serve as a filler to increase density of the micro structure et al., but also acts as an activator in the hydration reaction.

It is pertinent to note that improvement in strength of wood ash cement concrete over plain concrete was made possible at lower and higher curing ages by the addition of nanosilca up to the optimum level of $1.5 \%$. This is an improvement over the well-known characteristics of pozzolan cement concrete that only gain strength at higher curing ages. Thus, the low reactivity of wood ash cement concrete, especially at lower curing ages was enhanced by the incorporation of nanosilica into the mixture.

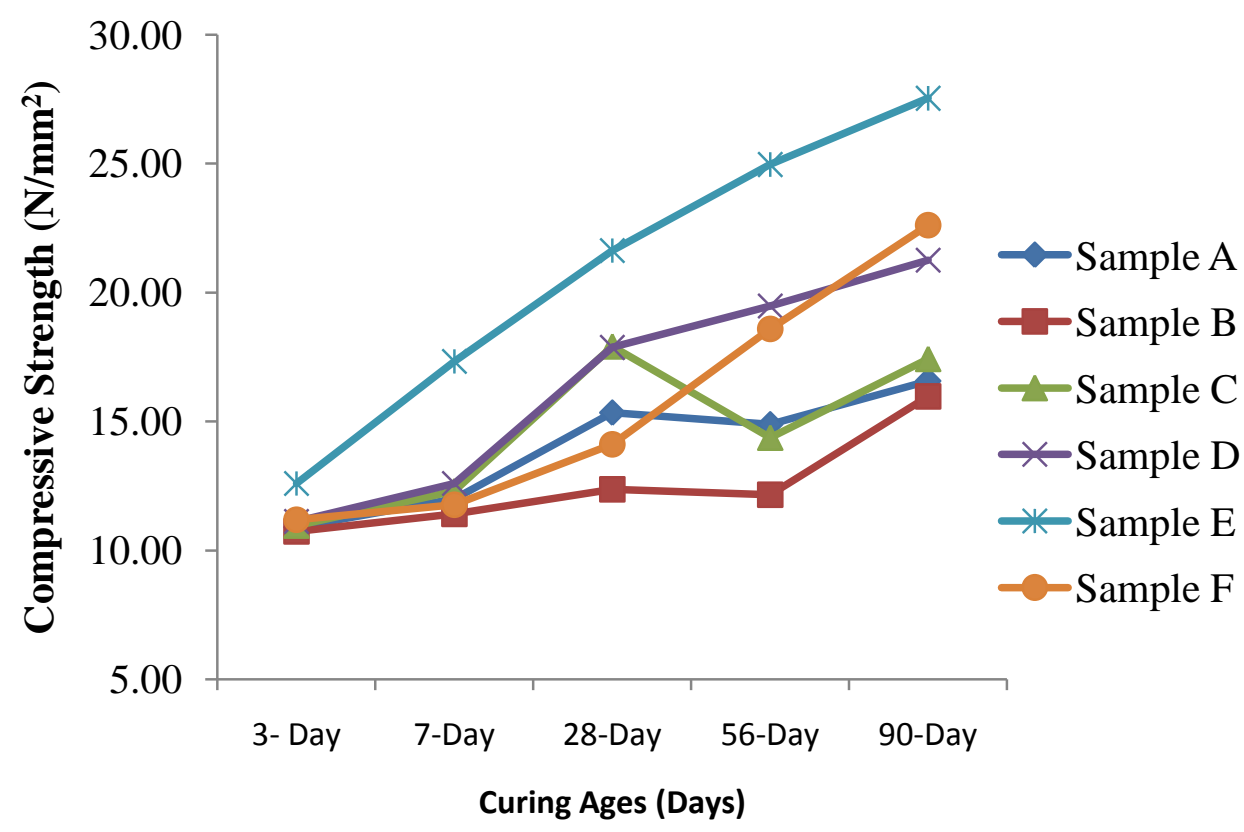

Figure 2: Effect of nanosilica on the compressive strength of concrete made with cement containing $10 \%$ wood ash

\section{Conclusion}

From the results of the various tests performed, the following conclusions were drawn:

i. Wood ash cement concrete becomes more workable with the addition of nanosilica into the mixture.

ii. Nanosilica improved the early and later compressive strength of wood ash cement concrete.

iii. The optimum level of nanosilica addition is at $1.5 \%$, for concrete containing $10 \%$ WA replacement for cement. 


\section{References}

Abdullahi, M. (2006) Characteristics of Wood Ash/OPC Concrete. Leonardo Electronic Journal of Practices and Technologies; 5 (8):9 - 16.

Adesanya, D. A. and Raheem, A. A.(2009) Study of the Workability and Compressive Strength Characteristics of Corn Cob Ash Blended Cement Concrete, Construction and Building Materials; 23: 311-317.

Adesanya, D. A. and Raheem, A. A. (2010) A Study of the Permeability and acid attack of Corn Cob Ash Blended Cement Concrete, Construction and Building Materials; 24: 403-409.

Antiohos, S. Maganari, K. and Tsimas, S. (2005) Evaluation of blends of high and low calcium fly ashes for use as supplementary cementing materials. Cement Concrete Composite; 2:349-56.

ASTMC 618-9 (1991) Standard specification for fly ash and raw or calcined natural pozzolan for use as minera admixture in Portland cement concrete. Annual book of ASTM Standards, Philadelphia, USA, ASTM.

Berra, M.; Carassiti, F.; Mangialardi, T.;Paolini, A. E. and Sebastiani, M. (2012) Effects of nanosilica addition on workability and compressive strength of Portland cement pastes. Construction and Building Materials; 35: 666-675.

Bowles, J. E. (1992) Engineering Properties of Soils and their Measurements, $4^{\text {th }}$ ed., New York, McGraw Hill.

BS 1881: Part 102 (1983) Method for determination of slump. London, British standard institution.

BS 1881: Part 103 (1983) Method for determination of slump. London, British standard institution.

Chowdhury, S.; Maniar, A. and Suganya, O. M. (2015) Strength development in concrete with wood ash blended cement and use of soft computing models to predict strength parameters. Journal of Advanced Research; 6: 907 - 913.

Ghafari, E.; Costa, H.; Juilo, E.; Portugal, A. and Duraes, L. (2014) The effect of nanosilica addition on flow ability, strength and transport properties of ultra high performance concrete. Materials and Design; 59: 1-9.

Jerath, S. and Hanson, N. (2007) Effect of fly ash content and aggregate gradation on the durability of concrete pavement. Journals of Material in Civil Engineering; 19(5): 367-375.

Lin, K.; Chang, W. C.; Lin, D. F.; Luo, H. L.and Tsai, M. C. (2008) Effect of nanosilica and different ash particle sizes on sludge ash-cement mortar. Journal of Environmental Management; 88: 708-714.

Mahender, B. and Ashok, R. (2017) Effect of Nano Silica on the Compressive Strength of Concrete. International Journal of Professional Engineering Studies; 8(2): 222-226.

Nazari A. and Riahi, S. (2011a ) The effects of $\mathrm{TiO}_{2}$ nanoparticles in flexural damage of self-compacting concrete. International Journal of Damage Mechanism; 20: 2049-2072.

Nazari A. and Riahi, S. (2011b) Improvement compressive strength of concrete in different curing media by $\mathrm{Al}_{2} \mathrm{O}_{3}$ nanoparticle. Material Science and Engineering A; 528: 1183 - 1191.

Nazari A. and Riahi, S. (2011c) The effects of $\mathrm{SiO}_{2}$ nanoparticles on physical and mechanical properties of high strength compacting concrete. Composites: Part B; 42: 570-578.

Raheem, A. A. and Adenuga, O. A. (2013) Wood ash from bread bakery as partial replacement for cement in Concrete. International Journal of Sustainable Construction Engineering \& Technology; 4(1): 75-81.

Raheem, A. A. and Kareem, M. A. (2017) Optimal raw material mix for the production of rice husk ash blended cement.Int. J. Sustain. Constr. Eng. Technol.; 7(2): 77-93.

Raheem, A. A.; Olasunkanmi, B. S. and Folorunso, C. S. (2012) Saw Dust Ash as Partial Replacement for Cement in Concrete.Organization, Technology and Management in Construction - An International Journal; 4(2): 472-478.

Saloma, N. A.; Imran, I. and Abdullah, M. (2015) Improvement of concrete durability by nanomaterials, Procedia Engineering; 125: 608-612. 
Siddique, R. (2012) Utilization of wood ash in concrete manufacturing.Resources, Conservation and Recycling; 67: 27-33.

Sikora, P.; Cendrowski, K.; Horzczaruk, E. and Mijowska, E. (2018) The effects of $\mathrm{Fe}_{3} \mathrm{O}_{4}$ andFe $\mathrm{O}_{3} / \mathrm{SiO}_{2}$ nanoparticles on the mechanical properties of cement mortars exposed to elevated temperatures. Construction and BuildingMaterials; 182: 441-450

Smith, G. N. and Smith, I. G. N. (1998) Elements of Soil Mechanics, 7th ed., Blackwell Science, London. Udoeyo, F. F.Inyang, H.; Young, D. T. and Oparadu, E. E. (2006) Potential of wood waste ash as an additive in concrete. Journal of Materials in Civil Engineering; 18(4): 605-11. 